\title{
KONTRIBUSI PASAR MODAL SYARIAH TERHADAP PEMBANGUNAN HUKUM PASAR MODAL NASIONAL
}

\author{
MUHAMMAD ALAMUL YAQIN, S.H.I
}

Bangkitnya ekonomi Islam di Indonesia dewasa ini menjadi fenomena yang menarik dan menggembirakan terutama bagi penduduk Indonesia yang mayoritas beragama Islam. Praktek kegiatan ekonomi konvensional, khususnya dalam kegiatan pasar modal yang mengandung unsur spekulasi sebagai salah satu komponennya nampaknya masih menjadi hambatan psikologis bagi umat Islam untuk turut aktif dalam kegiatan investasi terutama di bidang pasar modal. Instrumen-instrumen investasi syariah tersebut kemudian mengalami perkembangan sejalan dengan maraknya pertumbuhan bank-bank nasional yang membuka "window" syariah. Namun demikian, sampai saat ini regulasi yang khusus mengatur pasar modal syari'ah belum ada. Sehingga dalam pembangunan hukum pasar modal ke depan perlu mengedepankan nilai-nilai budaya bangsa yang merupakan konstruksi yang hidup dan dijalankan secara terus menerus dalam interaksi pelaku individu mayoritas bangsa Indonesia yang dijiwai syariat Islam.

Permasalahan dalam penelitian ini yaitu: bagaimanakah kedudukan pasar modal syari'ah dengan hukum pasar modal nasional dan bagaimana implikasi pasar modal syari'ah dan kontribusinya dalam pembangunan hukum pasar modal nasional. Adapun yang menjadi tujuan dalam penelitian ini yaitu: memahami kedudukan pasar modal syari'ah dengan hukum pasar modal nasional serta memahami implikasi pasar modal syari'ah dan kontribusinya dalam pembangunan hukum pasar modal nasional.

Penelitian ini menggunakan metode yuridis normatif dengan meneliti bahan pustaka mencakup penelitian terhadap asas hukum, perbandingan hukum, dan sejarah hukum. Adapun spesifikasi penelitian ini adalah deskriptif analitis. Sumber data yang digunakan dalam penelitian ini adalah bahan hukum primer dan bahan hukum sekunder. Sedangkan analisa yang digunakan dalam penelitian ini adalah analisa kualitatif.

Hasil penelitian menunjukkan bahwa kedudukan pasar modal syari'ah dengan hukum pasar modal nasional mempunyai keterkaitan yang erat dalam hal pembangunan ekonomi nasional. Dilihat dari keberadaan peraturan perundang-undangan, saat ini memang belum ada undang-undang khusus pasar modal syariah.. Meskipun demikian, praktek investasi secara syariah 
sudah berjalan sejak pertengahan 1997 melalui instrumen pasar modal berbasis syariah yaitu reksa dana syariah dan obligasi syariah. Sedangkan implikasi pasar modal syari'ah dan kontribusinya dalam pembangunan hukum pasar modal nasional telah terjadi dalam keseharian pelaksanaan transaksi ekonomi antar pelaku usaha baik yang berposisi sebagai investor maupun pengembang usaha. Terlihat bahwa prinsip-prinsip pasar modal Syariah sudah meliputi semua prinsip dari pasar modal yang ideal. Namun ada beberapa hal yang menjadi penekanan pada kehalalan produk/jasa dari kegiatan usaha, kegiatan usaha yang spesifik dengan manfaat yang jelas, mekanisme bagi hasil yang adil baik dalam untung maupun rugi menurut penyertaan masing-masing pihak dan mekanisme pasar yang wajar dan prinsip kehati-hatian baik pada emiten maupun investor.

Kata Kunci: Pasar Modal Syari'ah, Pembangunan Hukum, Pasar Modal Nasional

\section{RANGKUMAN.}

Pasar modal secara umum dapat diidentikkan dengan sebuah tempat dimana modal diperdagangkan antara pihak yang memiliki kelebihan modal (investor) dengan orang yang membutuhkan modal (issuer) untuk mengembangkan investasi. Dalam Undang-Undang No. 8 tahun 1995, pasar modal didefinisikan sebagai "kegiatan yang bersangkutan dengan Penawaran Umum dan perdagangan Efek, Perusahaan Publik yang berkaitan dengan Efek yang diterbitkannya, serta lembaga dan profesi yang berkaitan dengan Efek".

Keberadaan pasar modal di Indonesia merupakan salah satu faktor terpenting dalam ikut membangung perekonomian nasional, terbukti telah banyak industri dan perusahaan yang menggunakan institusi pasar modal ini sebagai media untuk menyerap investasi dan media untuk memperkuat posisi keuangannya. Secara faktual, pasar modal telah menjadi financial nerve centre (saraf finansial dunia) pada dunia ekonomi modern dewasa ini, bahkan perekonomian modern tidak akan mungkin bisa eksis tanpa adanya pasar modal yang tangguh dan berdaya saing global serta terorganisir dengan baik.

Sebagai upaya dalam mendukung terwujudnya Pasar Modal Indonesia menjadi penggerak ekonomi nasional yang tangguh dan berdaya saing global sebagaimana tertuang dalam cetak biru pasar modal Indonesia, perlu dilakukan secara terus menerus untuk menyempurnakan dan mengembangkan infrastruktur pasar modal menuju ke arah yang lebih baik lagi.

Salah satu faktor bagi terciptanya pasar modal Indonesia yang tangguh dan berdaya saing global dimaksud adalah dengan tersedianya fasilitas dan instrumen pasar modal Indonesia yang mampu bersaing dengan instrumen pasar modal negara-negara lain. 
Sehubungan dengan itu, ditengah kemerosotan tingkat pertumbuhan ekonomi nasional, yang juga berimbas ke sektor pasar modal selaku subsistem dari perekonomian nasional Indonesia, kini industri pasar modal Indonesia mulai melirik pengembangan penerapan prinsip-prinsip syariah islam sebagai alternatif instrumen investasi dalam kegiatan pasar modal di Indonesia.

Bangkitnya ekonomi Islam di Indonesia dewasa ini menjadi fenomena yang menarik dan menggembirakan terutama bagi penduduk Indonesia yang mayoritas beragama Islam. Praktek kegiatan ekonomi konvensional, khususnya dalam kegiatan pasar modal yang mengandung unsur spekulasi sebagai salah satu komponennya nampaknya masih menjadi hambatan psikologis bagi umat Islam untuk turut aktif dalam kegiatan investasi terutama di bidang pasar modal.

Perbedaan secara umum antara pasar modal konvensional dengan pasar modal syariah dapat dilihat pada instrumen dan mekanisme transaksinya, sedangkan perbedaan nilai indeks saham syariah dengan nilai indeks saham konvensional terletak pada kriteria saham emiten yang harus memenuhi prinsipprinsip dasar syariah. Secara umum konsep pasar modal syariah dengan pasar modal konvensional tidak jauh berbeda meskipun dalam konsep pasar modal syariah disebutkan bahwa saham yang diperdagangkan harus berasal dari perusahaan yang bergerak dalam sektor yang memenuhi kriteria syariah dan terbebas dari unsur ribawi, serta transaksi saham dilakukan dengan menghindarkan berbagai praktik spekulasi.

Langkah awal perkembangan pasar modal syariah di Indonesia dimulai dengan diterbitkannya Reksa Dana Syariah pada 25 Juni 1997 diikuti dengan diterbitkannya obligasi syariah pada akhir 2002, kemudian diikuti pula dengan hadirnya Jakarta Islamic Index (JII) pada Juli 2000. Instrumen-instrumen investasi syariah tersebut kemudian mengalami perkembangan sejalan dengan maraknya pertumbuhan bank-bank nasional yang membuka "window" syariah.

Dilihat dari kenyataannya, walaupun sebagian besar penduduk Indonesia mayoritas beragama Islam namun perkembangan pasar modal yang berbasis syariah dapat dikatakan sangat tertinggal jauh terutama jika dibandingkan dengan Malaysia yang sudah bisa dikatakan telah menjadi pusat investasi berbasis syariah di dunia, karena telah menerapkan beberapa instrumen keuangan syariah untuk industri pasar modalnya. Kenyataan lain yang dihadapi oleh pasar modal syariah kita hingga saat ini adalah minimnya jumlah pemodal yang melakukan investasi, terutama jika dibandingkan dengan jumlah pemodal yang ada pada sektor perbankan.

Pada sisi lain, harus diakui bahwa masih terdapat beberapa permasalahan mendasar yang menjadi kendala ber- 
kembangnya pasar modal yang berprinsip syariah di Indonesia. Kendala-kendala dimaksud diantaranya adalah selain masih belum meratanya pemahaman dan atau pengetahuan masyarakat Indonesia tentang investasi di pasar modal yang berbasis syariah, juga belum ditunjangnya dengan peraturan yang memadai tentang investasi syariah di pasar modal Indonesia serta adanya anggapan bahwa untuk melakukan investasi di pasar modal syariah dibutuhkan biaya yang relatif lebih mahal apabila dibandingkan dengan investasi pada sektor keuangan lainnya.

Dilihat dari sisi syariah, pasar modal adalah salah satu sarana atau produk muamalah. Transaksi didalam pasar modal, menurut prinsip hukum syariah tidak dilarang atau dibolehkan sepanjang tidak terdapat transaksi yang bertentangan dengan ketentuan yang telah digariskan oleh syariah.

Diantara yang dilarang oleh syariah adalah transaksi yang mengandung bunga dan riba. Larangan transaksi bunga (riba) sangat jelas, karena itu transaksi dipasar modal yang didalamnya terdapat bunga (riba) tidak diperkenankan oleh Syari'ah. Syari'ah juga melarang transaksi yang didalamnya terdapat spekulasi dan mengandung gharar atau ketidakjelasan yaitu transaksi yang didalamnya dimungkinkan terjadinya penipuan (khida'). Termasuk dalam pengertian ini: melakukan penawaran palsu (najsy); transaksi atas barang yang belum dimiliki (short selling/bai'u maalaisa bimamluk); menjual sesuatu yang belum jelas (bai'u ma'dum); pembelian untuk penimbunan efek (ihtikar) dan menyebarluaskan informasi yang menyesatkan atau memakai informasi orang dalam untuk memperoleh keuntungan transaksi yang dilarang (insider trading).

Dengan adanya berbagai ketentuan dan pandangan syariah seperti diatas, maka investasi tidak dapat dilakukan terhadap semua produk pasar modal karena diantara produk pasar modal itu banyak yang bertentangan dengan syari'ah. Oleh karena itu investasi di pasar modal harus dilakukan dengan selektif dan dengan hati-hati (ihtiyat) supaya tidak masuk kepada produk non halal. Sehingga hal inilah yang mendorong islamisasi pasar modal.

Sejak terbitnya buku Max Weber The Protestant Ethic and The Spirit of Capitalism (1904-5) orang yakin adanya hubungan erat antara (ajaran-ajaran) agama dan etika kerja, atau antara penerapan ajaran agama dengan pembangunan ekonomi. semangat permulaan kehadiran kapitalisme yang di tandai dengan orang-orang Eropa Barat yang mengadakan ekspansi perdagangan di berbagai negara di dunia.

Kapitalisme dalam arti khas, sebagai suatu sistem ekonomi yang merevolusikan perekonomian dunia, lahir di Eropa Barat dan Utara (Inggris, Belanda, Belgia, Perancis) dalam abad ke17. Hakikat kapitalisme adalah bahwa 
tujuan produksi bukanlah konsumsi pihak yang memproduksi, melainkan penambahan modal. Selama produksi ekonomis pada hakekatnya dijalankan untuk memenuhi kebutuhan sendiri, entah secara langsung, entah melalui perdagangan; tidak masuk akal untuk memproduksi melebihi kebutuhan maksimal. Batas alamiah bagi rasionalitas produksi itu hilang dalam kapitalisme baru, karena tujuannya adalah modal, sedangkan modal dapat diakumulasikan tanpa batas, dan makin kuat landasan modal sebuah perusahaan, makin kuat kedudukannya dalam proses ekonomi.

Kapitalisme-kolonialisme-Imperialisme Belanda yang pernah menjajah Indonesia kurang lebih 350 tahun telah mewariskan sistem hukum, sosial, budaya dan ekonominya di indonesia. Semua sistem itu hingga sekarang ini masih dilestarikan dan dipraktikkan oleh para pemegang kekuasaan di Indonesia. Sejarah ekonomi kolonial misalnya tidak lain dari sejarah kapitalisme baik dari, oleh dan demi negara (kolonial) dan swasta, sayangnya bukan swasta pribumi. Sejarah ekonomi kolonial adalah ekonomi kapitalisme yang termasuk juga didalamnya adalah lembaga pasar modal nasional.

Berdasarkan landasan filosofis, sosiologis dan yuridis, hukum yang berlaku di Indonesia mengandung dimensi transendental dan horisontal. Hukum dalam dimensi transendental berkaitan erat dengan substansi dan pengamalan sila pertama Pancasila, yaitu Ketuhanan Yang
Maha Esa, dalam Pasal 29 UndangUndang Dasar 1945. sedangkan hukum dalam dimensi horisontal, adalah tata aturan hidup yang mengatur kehidupan manusia.

Ada hubungan yang erat antara Pancasila sebagai dasar dan falsafah negara, dengan Undang-Undang Dasar 1945 sebagai hukum dasar, yang dijiwai oleh dan merupakan rangkaian kesatuan dengan Piagam Jakarta; sebagaimana dinyatakan dalam Dekrit Presiden 5 Juli 1959. Hubungan ini membawa pengaruh kepada tata nilai corak dan sisi hukum yang berlaku di Indonesia karena pada dasarnya; cara berfikir, pandangan hidup, karakter suatu bangsa tercermin dalam kebudayaan dan hukumnya. Pengaruh itu bermuara pada keinginan luhur bangsa; yaitu bahwa semua hukum yang berlaku harus bersumber dan dijiwai serta tidak boleh bertentangan dengan Pancasila dan Undang-Undang Dasar 1945.

Pancasila sebagai dasar dan falsafah Negara Indonesia yang mayoritas penduduknya beragama Islam, membawa konsekuensi, bahwa hukum di Indonesia harus tetap konsisten dengan dan dilandasi oleh nilai-nilai Ketuhanan Yang Maha Esa (yaitu sila pertama yang menyinari sila-sila lainnya) dan tidak mengabaikan hukum Islam. Menurut M. Thahir Azhary, "Di dalam negara hukum Pancasila, yang penting adalah hukum nasional, yang bersumber utamanya adalah hukum Islam selain Pancasila dan 
tidak bertentangan dengan nilai Pancasila itu sendiri".

Di dalam agama Islam, ekonomi dan sosial sangat erat hubungannya karena eratnya pertalian antara kebutuhan kebendaannya dan kepentingan batinnya, juga antara jasmaninya dan rohaninya. Keduanya tidaklah dapat dipisahkan, saling berhubungan serta saling berkaitan, sehingga disuatu waktu menjadi satu. Dalam meninjau suatu persoalan dari sudut ekonomi, kita tidak dapat melepaskannya dari sudut sosial.

Material dan moral harus berjalan bersama-sama untuk mencapai susunan ekonomi sosial yang sehat dan teratur. Jika material berjalan sendiri, dan segala hubungan manusia hanya diukur dengan ukuran kebendaan belaka, sebagai hasilnya hanya ukuran ekonomi dunia yang kapitalis sekarang, niscaya hancurlah hubungan yang baik dan berubahlah sifat manusia dari moralitasnya yang mulia menjadi hewan yang sangat rendah. Begitu pula sebaliknya, moral yang berjalan sendiri tanpa disertai material, hilanglah pula kebutuhan hidup manusia yang sangat dihayatinya di dunia ini.

Timbulnya kebutuhan-kebutuhan baru sebagai akibat pembangunan, perlu adanya kaidah-kaidah hukum baru yang dapat mengakibatkan adanya sistem hukum yang berbeda dengan sistem hukum yang ada. Untuk mengetahui apakah kaidah-kaidah hukum baru disamping bidang-bidang hukum yang ada, haruslah diadakan penelitianpenelitian untuk menemukan ciri-ciri khasnya, yang merupakan postulat yang mengakibatkan hukum itu dapat dipelajari sebagai satu kesatuan. Memperhatikan, bahwa perkembangan kehidupan ekonomi dominan, maka hukum ekonomi didefinisikan sebagai: "peraturan perundangundangan yang bersangkut paut dengan kehidupan ekonomi yang bersifat publik".

Peraturan-peraturan hukum yang tampaknya berdiri sendiri-sendiri tanpa ikatan, sesungguhnya diikat oleh beberapa pengertian yang lebih umum sifatnya, yang mengutarakan suatu tuntunan etis, berupa asas hukum. Asas hukum ini bisa memberikan penilaian etis terhadap hukum positif apabila ia tidak sekaligus berada diluar hukum tersebut. Keberadaan diluar hukum positif itu untuk menunjukkan, betapa asas hukum itu mengandung nilai etis yang self evident bagi yang mempunyai hukum positip itu. Karena adanya ikatan oleh asas-asas hukum, maka hukum pun merupakan suatu sistem. Peraturan-peratutan hukum yang berdiri sendiri itu lalu terikat dalam satu susunan kesatuan disebabkan karena mereka itu bersumber pada satu induk penilaian etis tertentu.

Tatanan hukum yang beroperasi dalam suatu masyarakat pada dasarnya merupakan pengejawantahan cita hukum yang dianut dalam masyarakat yang bersangkutan ke dalam perangkat berbagai aturan hukum positif, lembaga 
hukum dan proses (perilaku birokrasi pemerintahan dan warga masyarakat).

Rudolf Stammler (1856-1939) seorang ahli filsafat hukum yang beraliran neoKantian, berpendapat bahwa:

Cita hukum ialah konstruksi pikir yang merupakan keharusan bagi mengarahkan hukum kepada cita-cita yang diinginkan masyarakat dan cita hukum ini berfungsi sebagai bintang pemandu (leitstern) bagi tercapainya cita-cita masyarakat. Meski merupakan titik akhir yang tidak mungkin dicapai, namun cita hukum memberi manfaat, karena ia mengandung dua sisi, dengan cita hukum kita dapat menguji hukum positif yang berlaku dan kepada cita hukum kita dapat mengarahkan hukum positif sebagai usaha dengan sanksi pemaksa menuju sesuatu yang adil (zwangversuch zum richtigen). Oleh karena itu menurutnya, keadilan ialah usaha atau tindakan mengarahkan hukum positif kepada cita hukum. Dalam pokonya isi rechts ide tersebut katanya berisi konsep dasar dari hidup manusia yakni meliputi ide sosial. Isinya ialah ide tentang suatu masyarakat yang dengannya bebas dalam kehendak (ein gemeinschaft mit frei wollenden menschen). Dengan demikian, maka hukum yang adil (rictiges recht) ialah hukum positif yang memiliki sifat yang diarahkan oleh cita hukum untuk mencapai tujuan-tujuan masyarakat.

Dengan demikian, dalam pembangunan hukum di Indonesia perlu untuk didasarkan atas dua unsur penting didalamnya yaitu Rechts idee atau cita hukum dan Rechts begriif atau tatanan realita yang ada di dalam masyarakat. Sehingga akan berbagai peraturan-peraturan hukum yang posifif yang ada terutama dalam kancah hukum ekonomi di Indonesia pada gilirannya akan membentuk suatu sistem hukum yang sesuai dengan yang diinginkan masyarakat Indonesia secara keseluruhan. Sehingga produk hukum yang dihasilkan akan selalu sesuai dengan kekinian dan hidup.

Dalam penelitian mengenai pembaharuan hukum Islam di dunia Islam, J.N.D.Anderson dan Jhon L.Esposito berkesimpulan bahwa metode yang umumnya dikembangkan oleh pembaharu Islam dalam menangani isuisu hukum masih bertumpu pendekatan yang ad-hoc dan terpilah-pilah dengan menggunakan prinsip takhayyur dan talfiq. Akan tetapi terlepas benar atau tidaknya kesimpulan kedua tokoh tersebut perlu diteliti bagaimana kecenderungan hukum di negara-negara muslim masa kini.

Sistem-sistem hukum di dunia Islam sekarang secara garis besar bisa dibagi menjadi 3 kelompok: (1) sistemsistem yang masih mengakui syari'ah sebagai hukum asasi dan kurang lebihnya masih menerapkan secara utuh; (2) sistem-sistem yang meninggalkan syari'ah dan menggantikannya dengan hukum yang sama sekali sekuler, dan (3) sistem-sistem yang mengkompromikan kedua sistem tersebut. 
Di Indonesia harusnya memadukan antara konsep rechts idee (cita hukum) dan recht begrijf (realita hukum yang ada dalam masyarakat) dalam pembentukan hukum ekonomi nasional. Yaitu dalam pembangunan hukum ekonomi di Indonesia dengan berlandaskan pada konsep syari'ah karena mayoritas penduduk Indonesia memeluk agama Islam. Hal ini sesuai dengan hasil seminar hukum ke-8 di Bali yang mengamanatkan bahwa, dalam pembangunan hukum perlu untuk melakukan pendekatan budaya (culture) dan agama (religius). Hal tersebut bertujuan untuk mengurangi tingkat kesenjangan antara budaya hukum dengan sistem hukum yang ada.

Sistem hukum ekonomi nasional yang berbasis nilai-nilai ekonomi bangsa Indonesia adalah keyakinan dan perilaku mayoritas individu bangsa Indonesia, yaitu sistem ekonomi Islam. Sistem ekonomi Islam menurut Syed Nawab Haider Naqwi berakar kuat pada empat hipotesis, yaitu: (1) kegiatan ekonomi berhubungan erat, lewat kesatuan, dengan lingkungan etika manusia, berdasarkan kualitas dasar keseimbangan, harus diperoleh keseimbangan yang adil diantara dasar-dasar produksi, konsumsi dan saluran distribusi, (3) kehendak bebas yang dijabarkan kedalam bidang ekonomi individu dan pengendalian oleh negara, agar mencerminkan konsep khas Islam mengenai kebebasan manusia, dan (4) Aksioma pertanggungjawaban menuntut dibuatnya kebijaksanaan distribusi dan pengalihan sumber-sumber penghasilan diantara berbagai kelompok dan golongan masyarakat. Ini juga berarti bahwa peminjam dan pemberi pinjaman yang benar-benar mengetahui sifat kegiatan ekonomi yang penting dan penuh resiko itu.

Pendekatan yang dipergunakan oleh Naqwi tersebut, adalah pendekatan aksiologi, ini berarti teori sistem ekonomi Islamnya tidak lepas dari nilai-nilai yang menyertainya atau bertolak dari kerangka nilai. Dan teorinya berbeda dengan rasionalis. ekonomi (economics rationalists) yang tidak mempertimbangkan pengaruh kekuatan luar, khususnya faktor etika. Sedangkan nilainilai sistem ekonomi Islam sebagaimana pendapat yang dikemukakan oleh Muhammad Syafi'I Antonio adalah meliputi: (1) perekonomian masyarakat luas, bukan hanya masyarakat muslim, akan menjadi baik apabila menggunakan kerangka kerja atau acuan norma-norma Islami, (2) Keadilan dan persaudaraan menyeluruh yang implikasinya meliputi. (3) Keadilan sosial, (4) Keadilan ekonomi, (5) Keadilan distribusi pendapatan, (6) Kebebasan individu dalam konteks kebebasan sosial.

Dalam sistem ekonomi Islam karakter "manusia ekonomi", istilah yang sering digunakan dalam ilmu ekonomi, akan berubah sama sekali. Perilaku manusia ekonomi dalam mengoptimalkan suatu produksi yang semula bebas, kemudian akan dihadapkan kepada 
rambu-rambu kemaslahatan umat, kesejahteraan masyarakat dan "halalan thoyyiban" barang dan jasa yang dihasilkan harus bersih, sehat dan jelas cara memperolehnya tanpa merugikan orang lain atau mendholimi orang lain dan tanpa merusak kelestarian lingkungan hidup. Sistem ekonomi Islam ini dalam kehidupan berbangsa dan bernegara Indonesia telah mengkristal di dalam Pancasila, maka harus dipahami sistem ekonomi Pancasila.

Pancasila pada hakekatnya bukan hanya merupakan hasil perenungan atau pemikiran seseorang atau sekelompok orang sebagimana idiologi-idiologi lain di dunia, namun Pancasila merupakan rekontruksi dari nilai-nilai adat istiadat, nilai-nilai kebudayaan serta nilai-nilai religius yang terdapat dalam sikap dan pandangan hisup masyarakat Indonesia sebelum Negara Kesatuan Republik Indonesia terbentuk, bahkan NKRI dibentuk didasarkan pada Pancasila. Pancasila ini merupakan pandangan hidup (way of life), disamping itu juga sebagai dasar, jiwa dan kepribadian, tujuan yang akan di capai dan perjanjian luhur bangsa dan negara Indonesia. Oleh karena itu, di dalam Pancasila terdapat nilai-nilai yang dapat dijadikan pegangan hidup dan tata pergaulan dalam penyelenggaraan kehidupan ekonomi, tata kehidupan ekonomi ini sering disebut sebagai sistem ekonomi Pancasila.

Menurut Mubyarto, sistem ekonomi Pancasila adalah sistem ekonomi yang mempunyai lima ciri yaitu: (1) Roda perekonomian digerakkan oleh rangsangan ekonomi, sosial dan moral. (2) Kehendak kuat dari seluruh masyarakat kearah keadaan kemerataan sosial (egalitarianisme) sesuai asas-asas kemanusiaan. (3) Prioritas kebijakan ekonomi adalah penciptaan perekonomian nasional yang tangguh yang berarti nasionalisme menjiwai tiap kebijaksanaan ekonomi. (4) Koperasi merupakan soko guru perekonomian dan merupakan bentuk yang paling konkrit dari usaha bersama. (5) Adanya imbangan yang jelas dan tegas antar perencanaan ditingkat nasional dengan desentralisasi dalam pelaksanaan kegiatan ekonomi untuk menjamin keadilan ekonomi dan sosial.

Dua sistem ekonomi tersebut di atas dapat mendeskripsikan perilaku ekonomi dalam dunia usaha dan individuindividu masyarakat di Indonesia. dua sistem tersebut di atas dapat dipergunakan untuk menganalisis persamaan-persamaan dan perbedaan-perbedaan perilaku ekonomi diantara individu-individu dalam masyarakat tersebut, sehingga dapat ditemukan sistem ekonomi mana yang cocok sebagai basis sistem hukum ekonomi nasional, maka sistem hukum ini dalam perspektif teori hukum kritis adalah tidak netral, syarat dengan nilainilai. Dengan demikian di dalam pembangunan hukum ekonomi di Indonesia harus berwawasan nilai-nilai bangsa yaitu salah satunya adalah nilai Islam. 